\title{
Liposomal Eribulin Mesylate
}

National Cancer Institute

\section{Source}

National Cancer Institute. Liposomal Eribulin Mesylate. NCI Thesaurus. Code C111899.

A liposome-encapsulated formulation of the mesylate salt form of eribulin, a synthetic, macrocyclic ketone analogue of halichondrin $B$, a substance derived from the marine sponge genus Halichondria, with potential antineoplastic activity. Eribulin binds to the vinca domain of tubulin and inhibits both the polymerization of tubulin and the assembly of microtubules. This results in the inhibition of mitotic spindle assembly, the induction of cell cycle arrest at G2/M phase, as well as tumor cell apoptosis. Compared to the administration of eribulin alone, liposomal delivery of eribulin allows for a longer half-life, which allows increased drug concentration in target tissues while decreasing systemic toxicity. 